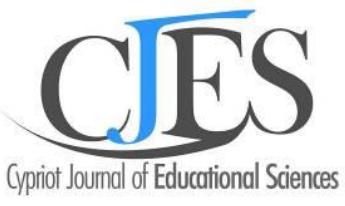

$\underline{\text { www.cjes.eu }}$

\title{
The implementation of balinese folflore-based civic education for strengthening character education
}

Dewa Bagus Sanjaya a *, Universitas Pendidikan Ganesha, Singaraja, 81116, Indonesia, https://orcid.org/00000002-0406-009X

I Kadek Suartama ${ }^{\text {b }}$, Universitas Pendidikan Ganesha, Singaraja, 81116, Indonesia, https://orcid.org/0000-0002$\underline{4881-3233}$

I Nengah Suastika ', Universitas Pendidikan Ganesha, Singaraja, 81116, Indonesia

Sukadi ${ }^{\text {, }}$ Universitas Pendidikan Ganesha, Singaraja, 81116, Indonesia

I Putu Mas Dewantara e, Universitas Pendidikan Ganesha Singaraja, 81116, Indonesia, https://orcid.org/0000$\underline{0003-4757-1751}$

\section{Suggested Citation:}

Sanjaya, D. B., Suartama, I. K., Suastika, I. N., Sukadi, Dewantara, I. P. M. (2021). The implementation of balinese folflore-based civic education for strengthening character education. Cypriot Journal of Educational Science. 16(1), 303-316 https://doi.org/10.18844/cjes.v16i1.5529.

Received from October 15, 2020; revised from December 20, 2020; accepted from February 05, 2021.

(C)2021 Birlesik Dunya Yenilik Arastirma ve Yayincilik Merkezi. All rights reserved..

\begin{abstract}
The objective of this study is to analyse the affectivity of satua (Balinese folklore)-based character education in the instructions of civic education in primary schools in Buleleng Regency, Bali. This study used the experimental design in testing the affectivity of folklore-based instructions in the competency and character of primary school students. The instruments used to collect data in this study were questionnaires, test of learning outcomes, score inventory and self-evaluation. The questionnaire was designed to find out the feasibility of folklore-based instructions. The test on learning outcomes was used to find out their scores. The data analysis used the multivariate analysis of variance. The results of the study indicated that a) learning using Balinese folklore is better than conventional learning in students' civic knowledge, b) learning using Balinese folklore is better than conventional learning in students' attitude and c) learning using Balinese folklore is better than conventional learning in students' skills.

Keywords: Balinese folklore, civic education, character education
\end{abstract}

\footnotetext{
* AdDRESS For CORRESPONDENCE: Dewa Bagus Sanjaya, Universitas Pendidikan Ganesha, Udayana Street No.11 Singaraja-Bali, 81116, Indonesia

E-mail address: bagus.sanjaya@undiksha.ac.id / Tel.: +62 817-559-622
} 
Sanjaya, D. B., Suartama, I. K., Suastika, I. N., Sukadi, Dewantara, I. P. M. (2021). The implementation of balinese folflore-based civic education for strengthening character education. Cypriot Journal of Educational Science. 16(1), 303-316 https://doi.org/10.18844/cjes.v16i1.5529.

\section{Introduction}

Civic education as an embodiment of character education in the practice of its instructions emphasises the attitude aspect without eliminating the cognitive and psychomotor aspects. Character is very essential in our lives as members of a nation/state (Winataputra, 2006). The loss of character will result in the loss of a nation's new generations. Character plays the roles of a 'steering wheel' and power for a nation to be steady. Character is not formed by itself, it has to be instilled and shaped in order to become a dignified nation.

Wuryandani and Wuri (2014) state that in carrying out character education in primary schools, there are nine policies that are implemented, namely 1) creating character education programmes; 2) establishing school and class rules; 3 ) conducting Duha and Dhuhr prayers in congregations; 4) creating affective posts in every class; 5 ) monitoring students' disciplinary behaviour at home by using the daily activity notebook; 6) giving affective messages in school corners; 7) involving parents; 8) involving school committee and 9) creating conducive class atmosphere. The establishment of character education faces six problems, namely a) the disorientation of Pancasila (the Five Pillars) and their values are not grasped fully yet, b) limitations of integrated policy instrument in manifesting the essential values of Pancasila, c) shifts in ethical values in people's lives as members of a community, a nation and a state, d) the fading of awareness of the country's cultural values, e) the threat of national disintegration and f) the weakening of the independence of the nation (Rachmah, 2013).

The facts in reality show that character education is faced by challenges of the fading of morality values and nationalism, the negligence of national identity, the increase in conflicts between ethnicities, races and religions and the fact that the national disintegration issue is getting stronger (Andiani, 2010). The real portrait of a nation's character degradation is the high rate of rape of children and women, free sex, drug use, fights between students/motor gang, woman/child trafficking, corruption collusion and nepotism, law mafia, justice/tax mafia, illegal logging, excessive exploitation of natural resources and robbery.

The implementation and practices of civic education only involve physical and low-level cognitive activities and lack mental activities with morality and spirituality dimensions. The materials and models of civic education that students learn in relation to moral behaviour tend to be based on the character education models and theories from the West that are not suitable with the social reality that grows and develops in Indonesia. They also tend to westernise (Kaelan, 2010; Winataputra, 2011). Kertih (2010) states that the learning model of civic education in primary schools, as an effective action of devotion, is developed from learning syntax with 10 learning phases. In line with the above statement, in the effort of developing the practice of civic education instructions, a more integrated and holistic idea needs to be developed (Djahiri, 2006). Civic education instructions need to be developed not only to give students civic knowledge, but also civic value and civic skills.

The development of civic education instructions with the dimensions of civic knowledge, attitude and skills as embodiments of character becomes very precise to be instilled with the community's local wisdom. Balinese's local wisdom that has philosophical values is Balinese cultural values that are built and developed based on the Tri Hita Karana ideology (Titib, 1995). Tri Hita Karana is derived from Tri which means three, hita which means prosperous and contended and karana which means cause. Besides Tri Hita Karana as a philosophical foundation, there are also Balinese folklore that are full of character values. The problems investigated in this study are 1) How is the profile of civic education instructions in primary schools in Bueleng Regency? 2) How is the affectivity of the implementation of Balinese folklore-based character instructions in the instructions of civic education in primary schools? 
Sanjaya, D. B., Suartama, I. K., Suastika, I. N., Sukadi, Dewantara, I. P. M. (2021). The implementation of balinese folflore-based civic education for strengthening character education. Cypriot Journal of Educational Science. 16(1), 303-316 https://doi.org/10.18844/cjes.v16i1.5529.

\section{Literature review}

\subsection{Civic education instructions}

Civic education has a very vital and strategic position in developing patriotism, nationalism and forming nation and character building (Unal \& Kaygin, 2019). However, in its implementation, it is very susceptible to the ruler's practical politics bias. Hence, it tends to be the instrument of the ruler rather than an instrument to form a nation's character. A similar thing also happens to developing countries, as stated by Cogan (in Suryadi \& Somantri, 2000). He stated that citizenship education has also often reflected the interests of those in power in a particular society and thus has been a matter of indoctrination and the establishment of ideological hegemony rather than of education. In line with the political changes and development from authoritarian to democratisation era, civic education has a few characteristics, namely a) the learning patterns are not indoctrinating and monolithic, b) the learning materials tend to form a civil society and c) give emphasis to the affective and psychomotor aspects without ignoring cognitive aspect.

Civic education aims to develop civic intelligence, embodiment of civic attitudes, civic skills, civic commitment, civic persistence and civic proficiency (Winataputra, 2011). The existence of civic education has to be understood as a path that is expected to lead Indonesia in creating democracy, good governance, a law-based nation and civil society that is relevant to the global demands. This expectation certainly has to be accompanied by the real actions of this nation, especially in the level of higher education, to appreciate and implement civic education in the education world. As a result, the learning outcomes of civic education will be very crucial in the development of democratic culture in Indonesia.

Civic education instructions have to be able to empower students to master and understand facts, data, concepts and generalisation in one body structure of civic education that covers political education materials, law awareness education, value education, moral education, character education, the education of the history of the nation's struggles, ideology education and social education generally (Bergersen \& Muleya, 2019). This includes verbal and procedural knowledge as well as intellectual strategies. The critical thinking skills cover the skills to identify, develop, describe, explain, analyse, evaluate, find and maintain opinions that are related to public issues. Meanwhile, participating skills include skills to interact, monitor and influence (Jerkovic, llic \& Elezovic, 2018).

Civic character has politeness which includes respect and human interaction, individual responsibility, self-discipline, concerns for the community and open-mindedness which includes openness, scepticism and compromise, which covers the principles of compromise boundary conflicts, tolerance towards diversity, patience and order, honesty, generosity and loyalty to the nation with all the principles. The development of a civic disposition will enable an effective political process to prioritise public interests and contribute to the manifestation of fundamental idea of the political system, which includes protection for individual rights. Civic character shows important private and public characters for the maintenance and development of constitutional democracy. Civic characters, as civic skills, develop gradually as a result of what has been learnt and experienced by someone at school, community and civil society organisations.

The development of a civic education learning model and instruments in primary schools will make it easier for teachers to conduct learning processes and develop the knowledge, attitudes and moral behaviour of the students. The development of this model will also help students in digging, formulating, describing, analysing and implementing knowledge, attitudes and moral behaviour in daily life in school environment, family and society (Lickona, 2013). 
Sanjaya, D. B., Suartama, I. K., Suastika, I. N., Sukadi, Dewantara, I. P. M. (2021). The implementation of balinese folflore-based civic education for strengthening character education. Cypriot Journal of Educational Science. 16(1), 303-316 https://doi.org/10.18844/cjes.v16i1.5529.

\subsection{Learning using Folklores}

Satua (Balinese folklore) normally use community language based on the position and function of satua as the folklore (Suarka, 2010). Satua, according to Pramuki (2011), is a folklore that can be used as learning media to make learning fun so that it can be an effective measure in improving character education. Nurgiantoro (2010) states that folklores are stories that come from the community and develop from generation to generation in the society in the past as a means of giving morals. Amir (2013) states that folklores have local wisdom, traditional intelligence, morals and sociocultural values.

The use of the right folklores in learning can motivate students to study. Pictures in the stories can help students to think, say and do something (Hasanah, 2012). Stories can build children's imagination and develop their creativity in thinking, talking and doing something. The learning of folklores that is inserted in civic education makes learning fun, not boring and strengthens students' characters.

\subsection{Strengthening of character education}

The strengthening of character education encourages education to pay attention to ethics and spirituality, aesthetic and kinaesthetic. These four dimensions in education should be carried out thoroughly and simultaneously. The integration of intracurricular, co-curricular and extracurricular learning processes at school can be carried out by using school culture development or collaborations with communities outside educational environment as the basis. Five main character values that are the priority of the character education strengthening movements are being religious, nationalism, integrity, independence and cooperation. Each value does not stand and develop by itself. They are connected with each other and are developed dynamically to form an individual unity (Suartama, Triwahyuni, Sukardi \& Hastuti, 2020).

Being religious shows faith in God that are manifested in the following practices: doing the things that have been taught by one's religion, respecting people of different religions, being tolerant of the practices of other religions and living in peace and harmony with people of different religions. The implementation of the religious character is shown by attitudes of living in peace, being tolerant of others, respecting people of different religions, taking a strong stand in something, being confident, cooperating well with people of different religions, not bullying and being violent, being able to make friends, being sincere, not imposing one's will, taking care of the environment and protecting unfortunate people.

Nationalist character is the way of thinking, behaving and doing something that shows high loyalty, concern and appreciation for one's language, physical, sociocultural, economic and political environments of one's nation and prioritising public before personal/group interests. Nationalist attitudes are shown by the attitudes of appreciating the culture of one's own nation, willingness to sacrifice, being outstanding and excellent in one's expertise, patriotism, taking care of the environment, abiding by the law, being disciplined and respecting diversity in culture, races and religions.

Integrity value is the value that underlies one's behaviours that are based on efforts of someone to make himself a reliable person in his/her words, actions and jobs and having commitment and loyalty to humanity values and moral values. The character of integrity includes responsibility as citizens, being active in social life through consistency of words and actions based on the truth. Someone with integrity also appreciates individual dignity (especially those with physical disabilities) and can become role models.

Independence is the attitude of not being dependent on someone else and using all energy, thoughts and time to realise hopes and dreams. Independent students have good work ethics, toughness, determination, professionalism, creativity, courage and are lifelong learners. 
Communal work or cooperation is shown by the attitudes of appreciating the spirit of cooperation and togetherness in solving problems, building communication and friendship and providing help/assistance for those in need. It is expected that students will be able to show attitudes of appreciating others, cooperating with others, being inclusive, having the commitment to accept mutual decisions, as well as deliberation and consensus, helping each other, having empathy and solidarity for others, not being discriminative, not being violent and are willing to volunteer for certain tasks.

Character education has two main objectives, namely policy and goodness. Education on goodness is the basis of democracy. Therefore, two important morals that have to be developed in character education are respect and responsibility. According to Lickona (2013), there are some values that have to be developed in character education. They are as follows: 1) honesty, 2) fairness, 3) tolerance, 4) prudence, 5) self-discipline, 6) helpfulness, 7) compassion, 8) cooperation, 9) courage and 10) democratic values.

Character is related to moral knowing, moral feeling and moral action. Moral knowing consists of six aspects, namely 1) moral awareness, 2) moral value knowing, 3) ability to give insight to others, 4) moral consideration and reasoning, 5) decision-making and 6) ability to recognise and understand one's self. Moral feeling has six components, namely 1) inner voice, 2) self-esteem, 3) empathy, 4) love for kindness, 5) ability to control oneself and 6) modesty. While moral action has three aspects, namely 1 ) moral competency, 2) willingness and 3) habit (Lickona, 2013).

Lickona (2013) proposes 11 principles of character education: 1) character education should develop 'core character value' as the basis for good character; 2 ) character education generally touches the affective aspect; 3) an effective character education demands a strong will, proactiveness and uses comprehensive approaches; 4) school as a caring community; 5) students have to be given the opportunity to do moral actions; 6 ) an effective character education has to involve a challenging and meaningful academic curriculum; 7) character education has to aim to develop students' intrinsic motivation; 8) all academics in school have to be learning society and have morals; 9) students have to be given access to moral leadership roles; 10$)$ school has to involve parents and community members and 11) the evaluation on character education has to measure the character of the school.

Interventional studies involving animals or humans, and other studies that require ethical approval, must list the authority that provides approval and the corresponding ethical approval code.

\section{Research Methodology}

\subsection{Research design}

This study is an experimental study that tests the main impact of the independent variable on the dependent variable. This study uses a quasi-experimental pre-test-post-test non-equivalent control group design. The independent variable is the learning strategy (learning with Balinese folklore and conventional learning) and the dependent variable is the learning outcomes (cognitive, affective and psychomotor).

\subsection{Participants}

The subjects of the study were grade VI students of primary schools in Buleleng Regency. There were 360 students who were divided into 18 classes ( 9 experimental classes and 9 as control classes). The experimental classes consist of 89 boys and 91 girls and the control classes consist of 180 students: 88 boys and 92 girls. These students were all registered in the civic education subject in the second 
Sanjaya, D. B., Suartama, I. K., Suastika, I. N., Sukadi, Dewantara, I. P. M. (2021). The implementation of balinese folflore-based civic education for strengthening character education. Cypriot Journal of Educational Science. 16(1), 303-316 https://doi.org/10.18844/cjes.v16i1.5529.

semester. The experimental and control classes were chosen by using the random sampling technique with the assumption that all data are homogeneous.

\subsection{Instruments}

The research data were collected through techniques of document study, in-depth interview and observation. Document study, interview and observation were used to collect data on the learning profile conducted by the teacher. For document study, the instruments used were document analysis/study formats and guidance. To collect data through in-depth interview, the researchers developed unstructured in-depth interview guidelines. Meanwhile, for observation, the researchers develop unstructured observation guidelines related to the various learning activities in class and students' activities in the learning process. The collection of the main data, in the forms of the results of the test of folklore-based civic education learning, was carried out by using objective tests.

\subsection{Procedures}

The researchers conducted a study directly on two experimental classes and two control classes. In the experimental classes, the researchers implemented learning activities using the strategy of using Balinese folklores; meanwhile, in the control classes, the learning activities were conducted using a conventional strategy.

The researchers carried out the pre-test in both research subjects simultaneously. This was carried out to find out the extent of the students' ability (cognitive, affective and psychomotor) before the experiment was conducted. Afterwards, the learning activities were carried out by implementing the strategy of using folklores in experimental classes and conventional learning in control classes.

The strategy of using Balinese folklores was implemented in line with the subject, namely civic education. The steps in implementing the Balinese folklore-based instruction were as follows:

(1) The teacher gives apperception;

(2) The teacher introduces a story that probably has been read by some students;

(3) The teacher gives chances for the students to read the story;

(4) The teacher gives explanation about the story;

(5) The teacher assigns the students to find out the characters in the story;

(6) The teacher assigns the students to find out the setting of the story, for example, rice field, farm, garden or woods;

(7) The teacher encourages the students to answers by asking questions about who can be considered as role models in the story;

(8) For the closing activity, the teacher carries out formative evaluation based on the learning objectives.

After all the learning steps are completed, the researchers conduct a post-test (cognitive, affective and psychomotor) at the end of the research to examine the extent of the success of the strategy used.

\subsection{Data analysis}

Quantitative data analysis is implemented in this study to find out the affectivity of the implementation of Balinese folklore-based civic education instruction. The statistical analysis used in the experimental model is the multivariate analysis of variance (MANOVA) test. 
Sanjaya, D. B., Suartama, I. K., Suastika, I. N., Sukadi, Dewantara, I. P. M. (2021). The implementation of balinese folflore-based civic education for strengthening character education. Cypriot Journal of Educational Science. 16(1), 303-316 https://doi.org/10.18844/cjes.v16i1.5529.

\section{Findings}

\subsection{The description of the pre-test data}

The results of the pre-test of civic education (civic ability, score inventory and self-evaluation on the civic social skills) of the students are presented in Table 1.

Table 1. The results of the pre-test (citizenship ability, score inventory and self-evaluation on civic social skills)

\begin{tabular}{clcccc}
\hline \multirow{2}{*}{ Learning method } & N & Mean & Std. deviation & $\begin{array}{c}\text { Std. error } \\
\text { mean }\end{array}$ \\
\hline \multirow{2}{*}{ Affective } & Conventional & 180 & 73.9333 & 0.45587 & 0.03398 \\
& Using Balinese Folklores & 180 & 73,9722 & 0.38738 & 0.02887 \\
& Conventional & 180 & 73.9722 & 0.35737 & 0.02664 \\
& Using Balinese Folklores & 180 & 73.9889 & 0.27944 & 0.02083 \\
& Conventional & 180 & 74.0000 & 0.23636 & 0.01762 \\
& Using Balinese Folklores & 180 & 73.9722 & 0.28814 & 0.02148 \\
\hline
\end{tabular}

As seen from the overall measurement results, there is no significant difference in the outcomes of the learning in the aspects of knowledge, attitudes and skills in both control and experimental classes. This gives us a picture that the ability of the research subjects before the research is conducted is not really different. The pre-test results of the civic instruction in the aspects of knowledge, attitude and skills then are analysed using independent sample t-test to examine the significance of the learning outcomes before the implementation of Balinese folklore and conventional methods. The results of the analysis of the difference of the learning outcomes in the aspects of knowledge, attitude and skill from the pre-test is presented in Table 2.

Table 2. Independent samples t-test

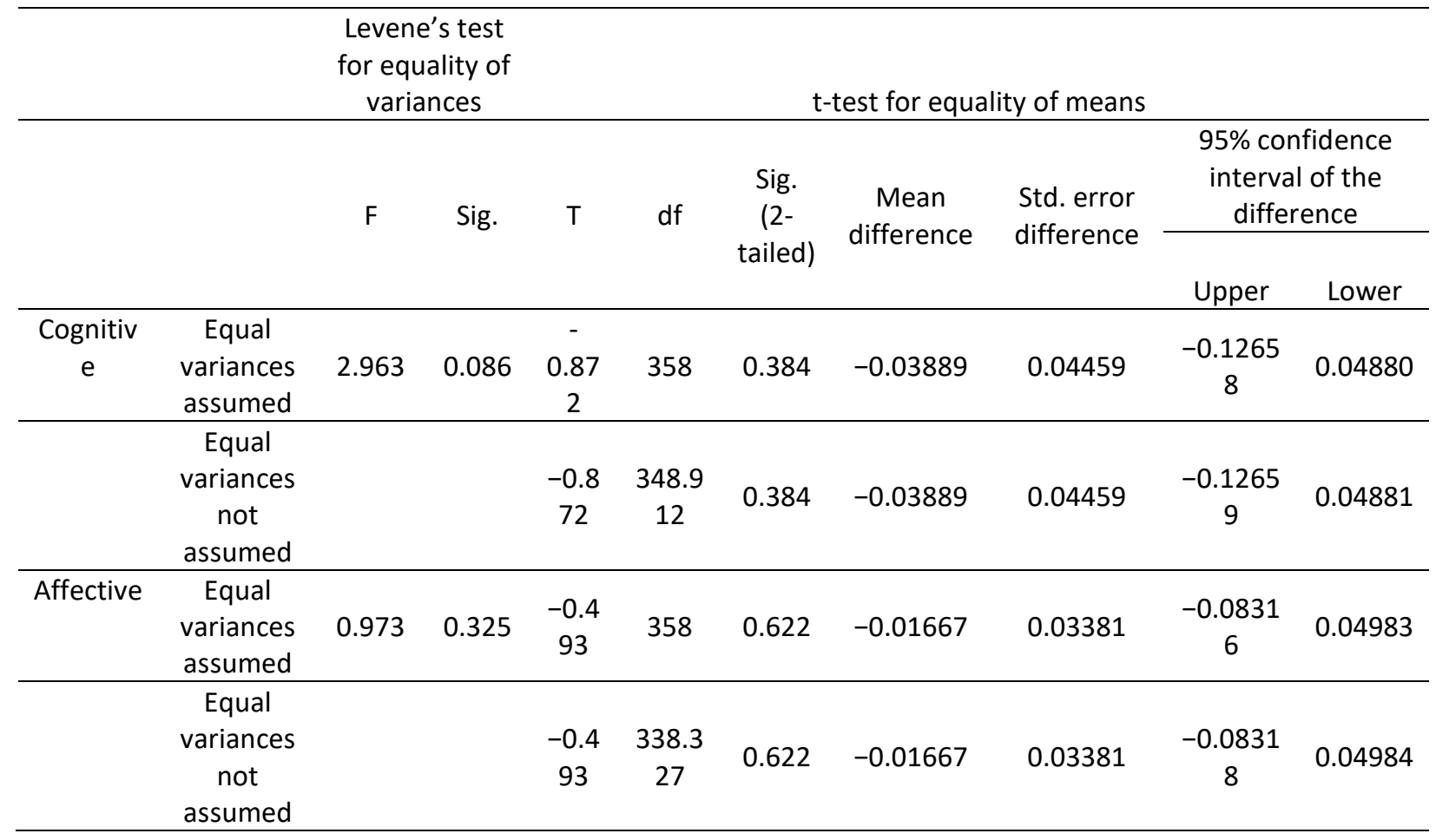


Sanjaya, D. B., Suartama, I. K., Suastika, I. N., Sukadi, Dewantara, I. P. M. (2021). The implementation of balinese folflore-based civic education for strengthening character education. Cypriot Journal of Educational Science. 16(1), 303-316 https://doi.org/10.18844/cjes.v16i1.5529.

\begin{tabular}{|c|c|c|c|c|c|c|c|c|c|c|}
\hline $\begin{array}{c}\text { Psychom } \\
\text { otor }\end{array}$ & $\begin{array}{c}\text { Equal } \\
\text { variances } \\
\text { assumed }\end{array}$ & 1.417 & 0.235 & $\begin{array}{c}1.00 \\
0\end{array}$ & 358 & 0.318 & 0.02778 & 0.02778 & $\begin{array}{c}-0.0268 \\
5\end{array}$ & 0.08241 \\
\hline & $\begin{array}{c}\text { Equal } \\
\text { variances } \\
\text { not } \\
\text { assumed }\end{array}$ & & & $\begin{array}{c}1.00 \\
0\end{array}$ & $\begin{array}{c}344.8 \\
17\end{array}$ & 0.318 & 0.02778 & 0.02778 & $\begin{array}{c}-0.0268 \\
6\end{array}$ & 0.08241 \\
\hline
\end{tabular}

Table 2 shows that the scores of Sig Levene's test are 0.086 (knowledge), 0.325 (attitude) and 0.235 (skill). These three significance scores are bigger than 0,05 and it can be concluded that there is no difference in the variances of the scores of knowledge, attitude and skill between the experimental and control classes. Hence, the test can be conducted by the independent $t$-test with the assumption that the data are homogeneous. The result of the t-test of the learning outcomes in the aspect of knowledge of the experimental and control classes shows a significance score $[t(358)=-0.872, p=0.384, p>0.05$; $\mathrm{HO}$ is accepted], which means that there is no significant difference in the scores of the learning outcomes between the two classes. The result of the independent t-test of the learning outcomes in the aspect of attitude of the experimental and control classes shows a significance score [ $t(358)=-0.493$, $\mathrm{p}=0.622, \mathrm{p}>0.05 ; \mathrm{HO}$ is accepted). Additionally, the independent t-test of the learning outcome in the aspect of skill between experimental and control classes shows a significance score [t $(358)=1.00, p=$ $0.318, \mathrm{p}>0.05$; $\mathrm{HO}$ is accepted], which means that there is no significant difference in the learning outcomes in the aspect of skill between both classes. In other words, before the treatment of implementing Balinese folklore and conventional methods is given, the learning outcomes of the experimental and control classes in the aspects of knowledge, attitude and skill are not really different or relatively the same.

\subsection{The data description post-test results}

The recapitulation of the post-test of the students' civic education learning outcomes (cognitive, affective and psychomotor) is presented in Table 3.

Table 3. Post-test learning outcomes (cognitive, affective and psychomotor)

\begin{tabular}{|c|c|c|c|c|}
\hline & Learning method & Mean & Std. deviation & $\mathrm{N}$ \\
\hline \multirow[t]{3}{*}{ Cognitive } & Conventional & 81.0056 & 4.34220 & 180 \\
\hline & Using Balinese Folklores & 83.8722 & 5.95986 & 180 \\
\hline & Total & 82.4389 & 5.40109 & 360 \\
\hline \multirow[t]{3}{*}{ Affective } & Conventional & 79.8444 & 4.89079 & 180 \\
\hline & Using Balinese Folklores & 82.0889 & 5.54946 & 180 \\
\hline & Total & 80.9667 & 5.34274 & 360 \\
\hline \multirow[t]{3}{*}{ Psychomotor } & Conventional & 79.7056 & 4.95533 & 180 \\
\hline & Using Balinese Folklores & 81.2611 & 5.69854 & 180 \\
\hline & Total & 80.4833 & 5.38902 & 360 \\
\hline
\end{tabular}

Table 3 shows that the learning outcomes in the aspect of knowledge in the control (conventional) classes were $\mathrm{M}$ score $=81.00$ and $\mathrm{SD}=4.34$, while in the experimental (Balinese folklore) classes they were $\mathrm{M} \mathrm{score}=83.87$ and SD score $=5.95$. The learning outcomes in the aspect of attitude in the control (conventional) classes were $\mathrm{M}$ score $=\mathbf{7 9 . 8 4}$ and $\mathrm{SD}=4.89$, while in the experimental (Balinese folklore) 
Sanjaya, D. B., Suartama, I. K., Suastika, I. N., Sukadi, Dewantara, I. P. M. (2021). The implementation of balinese folflore-based civic education for strengthening character education. Cypriot Journal of Educational Science. 16(1), 303-316 https://doi.org/10.18844/cjes.v16i1.5529.

classes they were $M$ score $=82.08$ and SD score $=5.54$. The learning outcomes in the aspect of skill in control (conventional) classes were $\mathrm{M}$ score $=79.70$ and $\mathrm{SD}=4.95$, while in the experimental (Balinese folklore) classes they were $\mathrm{M}$ score $=81.26$ and SD score $=5.69$.

\subsection{Prerequisite Test Results}

\subsubsection{Multivariate normality test}

To determine whether the samples are taken from the population are normally distributed, the multivariate normality test was conducted by using the correlation between the Mahalanobis distance and chi-square. The result of the analysis is presented in Table 4.

Table 4. The results of the multivariate normality test

\begin{tabular}{cc}
\hline Correlation coefficient & $p$ Value \\
\hline 0.955 & 0.000 \\
\hline
\end{tabular}

Table 4 shows that the $p$-value for the multivariate normality test was 0.000 . This value is smaller than the critical value 0.05 , so that the assumption that the samples are taken from the normally distributed population is accepted.

\subsubsection{Variance homogeneity test}

To determine whether the samples are taken from the population with homogeneous variances, the homogeneity test using Levene's test is conducted. The test results are presented in Table 5.

Table 5. Homogeneity test results

\begin{tabular}{cc}
\hline Category & p Value \\
\hline Cognitive & 0.000 \\
Affective & 0.000 \\
Psychomotor & 0.006 \\
\hline
\end{tabular}

As shown in Table 5, the p-values of the variance homogeneity test in all categories are smaller than the critical value 0.05 . Therefore, the assumption that the samples come from population with homogeneous variances is rejected. However, as MANOVA is robust (resistant against violation of assumption), the test can still be conducted.

\subsubsection{Variance/covariance matrix similarity test}

The result of the variance/covariance matrix similarity test is presented in Table 6.

Table 6. Variance/covariance matrix similarity test

\begin{tabular}{cc}
\hline F-value & p-value \\
\hline 26.787 & 0.000 \\
\hline
\end{tabular}

From the Table 6 , it can be seen that the significance score of the variance/covariance matrix similarity test is 0.000 . This is smaller than the critical value 0.05 , so that the assumption that the variance/covariance matrices of the dependent variables are similar is rejected. As MANOVA test is robust, the test can still be conducted. 
Sanjaya, D. B., Suartama, I. K., Suastika, I. N., Sukadi, Dewantara, I. P. M. (2021). The implementation of balinese folflore-based civic education for strengthening character education. Cypriot Journal of Educational Science. 16(1), 303-316 https://doi.org/10.18844/cjes.v16i1.5529.

\subsection{The Results of Hypothesis Test}

To examine if there were different impacts of conventional learning and learning using Balinese folklores on students' knowledge, attitude and skill level, a MANOVA test was conducted. The results of the test which is carried out with the assistance of SPSS are presented in Table 7.

Table 7. MANOVA test results

\begin{tabular}{cc}
\hline Statistical tests & p Value \\
\hline Pillai's trace & 0.000 \\
Wilk's Lambda & 0.000 \\
Hotelling's trace & 0.000 \\
Roy's largest root & 0.000 \\
\hline
\end{tabular}

As the assumptions on variance homogeneity are not met, the statistical test conducted was Pillai's Trace test. Table 7 shows that the significance value of the test is 0.000 . This is smaller than the critical value 0.05 . Hence, the following conclusions can be drawn:

(1) Learning using Balinese folklore is better than conventional learning in the aspect of students' civic ability;

(2) Learning using Balinese folklore is better than conventional learning in students' score inventory;

(3) Learning using Balinese folklore is better than conventional learning in the self-evaluation on students' civic social skills.

\section{Disscussions}

Balinese folklore-based learning that is developed in the instructions of civic education basically asserts civic education as character education. Nurgiantoro (2010) states that folklores are stories that come from the society and develop from generation to generation in the society in the past as a means to give morals. Amir (2013) states that folklores contain local wisdom, traditional intelligence, moral values and sociocultural values. One of the objectives of civic education is to provide students with moral skills to live peacefully according to the religious, social and local values. A nation with no character and self-identity in globalisation context will be an object in the global world.

A nation's existence is highly determined by its characteristics. Only nations with strong characters can become dignified nations and respected by other nations. Therefore, all nations, including Indonesia, have to be nations with characters. School failures, for children, are not based on the cognitive ability, but psychosocial factors (emotional and social intelligence), such as confidence, curiosity, motivation, self-control, cooperation, empathy and communication ability (Megawangi, 2004).

Ghufron (2010) asserts that the integration of the values of a nation's characters can be carried out in the learning activities of all subjects in school to enable the graduates to master competency and implement the nation's character values in daily life. Carr (2007) states that a good character is a very essential thing for human life, but is not explicitly given in the educational process.

Wuryandani and Wuri (2014) argue that the implementation of discipline character education in primary schools can be made through nine policies, namely (1) creating character education programme; (2) establishing school and class rules; (3) conducting Duha and Dhuhr prayers in congregation; (4) creating affective poster in every class; (5) monitoring students' disciplinary behaviour at home by using daily activity notebook; (6) putting affective messages in various school corners; (7) involving parents; (8) involving school committee and (9) creating a conducive class atmosphere. 
Sanjaya, D. B., Suartama, I. K., Suastika, I. N., Sukadi, Dewantara, I. P. M. (2021). The implementation of balinese folflore-based civic education for strengthening character education. Cypriot Journal of Educational Science. 16(1), 303-316 https://doi.org/10.18844/cjes.v16i1.5529.

Zuchdi (2010) states that the effective character education model is the one using the comprehensive approach. Learning is not only in one certain subject, but also integrated in various subjects. The methods and strategies used are varied, and as much as possible include inculcation (not indoctrination), providing exemplary behaviour, facilitating values and developing soft skills (thinking critically, creative, communicating effectively and able to solve problems) (Suartama et al., 2021). Civic education is a compulsory subject at all levels of school education in Indonesia (Komalasari \& Saripudin, 2018).

The results of the research carried out by Parmini (2015) in Ubud Bali show that Balinese folklore can increase the emotional intelligence of students in primary schools. The results of a study by Sanjaya and Sukadi (2018) about Balinese folklore-based in Bali indicate that there are not many teachers who have used Balinese folklore in instilling characters learning model in primary schools in students. The above condition and reality made us interested in conducting a more comprehensive and in-depth research. This is in line with the direction of the policy of our national education in 2020 that gives emphasis on character education and competency.

Samsuri and Marzuki (2016) conducted a research on forming multicultural civic characters in Islamic Senior High Schools and efforts in harmonising Islamic national identities in Islamic Senior High Schools. The results of the research indicate that the strengthening of the integration of Islamic and national values in the multicultural face of modern Indonesia Islamic education needs to be further elaborated. Wuryandani (Goode, 2003) asserts that (1) the policy of building independence in the students of the Islamic schools is implemented through learning independence, managing themselves and managing their time; (2) for independence in the learning process, the teachers use the assignment strategy that demands the students to independently use the learning sources, make learning contract and integrate character education of being independent in the teaching and learning process in class (3) the obstacles faced by the schools in implementing the character education of being independent are parents' inconsistency and the fact that some teachers do not yet integrate character education of being independent in the learning process.

There are six problems that this nation faces in building its character, namely 1 ) disorientation of the values of Pancasila (the Five Principles) or the fact that Pancasila values are not understood fully and felt by the people yet; 2 ) limitation of integrated policy instrument in manifesting the essential values of Pancasila; 3 ) shift in ethical values in people's lives as members of a society, a nation and a state; 4) the fading of awareness of nation's cultural values; 5) the threat of national disintegration and 6) the weakening of the independence of the nation.

Some behaviours that indicate the degradation of moral values in social and national life can be seen in our society. This is in line with the analysis that has been proposed by Lickona (2013) regarding the characteristics of a nation that is on the verge of collapse: 1 ) the increase of violence among teenagers; 2 ) the use of worse words and language; 3) strong influence of peer group in violent actions; 4) an increase in self-destructive actions; 5 ) the guidelines of good and bad moral are getting more blurred; 6) the decrease in work ethics; 7) the decrease in respects towards parents and teachers; 8) low individual responsibility and responsibility as a citizen; 9) being dishonest and 10) being suspicious and hateful towards others.

Seeing that these characteristics are getting evident, it is getting clearer that this nation is on the verge of a collapse. All those characteristics have become everyday behaviour and phenomena of this nation. This condition directly shows the urgency of the need of moral skills in learning practices whose processes will be through training and habit formation until they eventually can become a part of the culture. 
Moral degradation that takes place in various places has the potential to trigger bigger destruction, if not overcome by using various ways and media including education. Education is a strategic mode for the development and forming of attitudes, characters and students' identity to become smart, competitive individuals that have moral awareness. For that, this education of kindness is supposed to take place, starting from kindergarten until higher education. In the kindergarten level, students are introduced to simple and easy to do, but essential moral, skills, so that they will understand that moral behaviour is very important for their lives in the future. In the primary school level, besides being taught concepts of moral actions, students should also be trained how to behave based on the accepted moral values in their lives as members of a society, a nation and a state.

The values that can be built and developed in the learning practices in primary school level are being honest, tolerant, disciplined, hardworking, creative, independent, democratic, curious, patriotic, appreciating achievements, being friendly/communicative, loving peace, being fond of reading, caring about the environment and having social awareness and responsible (Alcalá, Garijo, Pérez-Pueyo \& Fernández-Río, 2019). The moral skills that can be developed in the learning practices in primary school level are skills in communicating, skills in socialising, ability to take responsibility, skills to be democratic, ability to build achievements and ability to solve problems that take place in the school and community environment. In this stage, the awareness on differences between one human and others has grown, including awareness on the attitudes and behaviours that are in line with the accepted religious, society and local values. In this context, it seems that providing examples of moral behaviour, training moral habits and forming habit of moral behaviour are appropriate operationalisation of concrete operational way of thinking.

The results of the empirical analysis indicate that to improve the quality of students' learning process and outcomes, it is compulsory for every teacher to make and develop their own learning instrument independently, based on the subjects and classes that they teach. In relation to that, it is mandatory for every civic education teacher to make yearly programme, semester programme, syllabus and lesson plans for one semester.

Most teachers admit that civic education instruction in primary schools in Buleleng regency has not implemented innovative learning. The teachers admit that innovative learning is very good, but they are not able to implement it in their teaching; moreover, innovative learning in relation to character education. Almost all teachers say that the innovative learning model is needed in the practice of civic education, including in the basic competency and the materials that are full of character contents.

The practice of character learning needs more students' direct involvement to find out, to be given examples to, to be trained and to get used to displaying characters that should be reflected in learning (Amri, Djatmika, Wahyono \& Widjaja, 2020). Learning using Balinese folklore is better than conventional learning in the aspect of students' civic ability. Learning using Balinese folklore is better than conventional learning in the students' score inventory and learning using Balinese folklore is better than conventional learning in the students' self-evaluation on their social civic skills. It really makes sense that learning that is carried out by using Balinese folklore can create good characters, such as being imaginative and honest.

\section{Conclusions}

The objective of this study is to analyze the effectivity of satua (Balinese folklore)-based character education in the instructions of Civic Education in Primary Schools in Buleleng Regency, Bali. The research found Learning using Balinese folklores is better than conventional learning in the aspect of students' civic ability. Learning using Balinese folklores is better than conventional learning in the 
Sanjaya, D. B., Suartama, I. K., Suastika, I. N., Sukadi, Dewantara, I. P. M. (2021). The implementation of balinese folflore-based civic education for strengthening character education. Cypriot Journal of Educational Science. 16(1), 303-316 https://doi.org/10.18844/cjes.v16i1.5529.

students' score inventory, and learning using Balinese folklores is better than conventional learning in the students'self-evaluation on their social civic skills. It really makes sense that learning that is done by using Balinese folklores can create good characters, such as being imaginative and honest.

\section{References}

Alcalá, D. H., Garijo, A. H., Pérez-Pueyo, Á., \& Fernández-Río, J. (2019). Cooperative Learning and Students' Motivation, Social Interactions and Attitudes: Perspectives from Two Different Educational Stages. Sustainability, 11(7005). https://doi.org/10.3390/su11247005

Amir, A. (2013). Sastra Lisan Indonesia. CV Andi Offset. http://opac.balikpapan.go.id:8123/inlislite3/opac/detailopac?id=15840

Amri, F., Djatmika, E. T., Wahyono, H., \& Widjaja, S. U. M. (2020). The Effect of Using Simulation on Developing Students' Character Education in Learning Economics. International Journal of Instruction, 13(4), ., 13(4), 375-392. https://doi.org/https://doi.org/10.29333/iji.2020.13424a

Andiani. (2010). Membentuk Manusia Berkarakter dan Beradab. Seminar Internasional UPI Bandung.

Bergersen, A., \& Muleya, G. (2019). Zambian Civic Education Teacher Students in Norway for a Year-How Do They Describe Their Transformative Learning? Sustainability, 11(7143). https://doi.org/10.3390/su11247143

Carr, D. (2007). CHARACTER IN TEACHING. British Journal of Educational Studies, 55(4), 12. https://doi.org/10.1111/j.1467-8527.2007.00386.x

Djahiri, H. K. (2006). Esensi Pendidikan Nilai-Moral dan PKN di Era Globalisasi. Lab. PKN FPIPS-UPI.

Ghufron, A. (2010). Integrasi Nilai-Nilai Karakter Bangsa Pada Kegiatan Pembelajaran. Cakrawala Pendidikan, Spesial Is(Dies Natalis UNY). https://doi.org/10.21831/Itr.v11i1.1150

Goode, C. M. (2003). Evaluating the Quality, Usability, and Potential Effectiveness of Online Learning Modules: A Case Study of Teaching with Technology Grant Recipients at the University of Tennessee, Knoxville [University of Tennessee]. https://trace.tennessee.edu/utk_graddiss/4291

Hasanah, M. (2012). Model Cerita Fiksi Kontemporer Anak-Anak untuk Pengembangan Kemahirwicaraan Siswa Kelas 5 Sekolah Dasar. Jurnal LITERA, 11(1). https://doi.org/https://doi.org/10.21831/Itr.v11i1.1150

Jerković, L., llić, M., \& Elezović, S. J. (2018). The Effects of Civic Education Instruction. Didaktika SlovenicaPedagoška Obzorja, 2(4), 55-65. https://www.researchgate.net/publication/331312758_The_Effects_of_Civic_Education_Instruction

Kaelan. (2010). Pendidikan Pancasila. https://openlibrary.telkomuniversity.ac.id/pustaka/22189/pendidikan-pancasila-edisi-reformasi-2010.html

Kertih, I. W. (2010). A Reconstruction of the Thinking of Primary School Civics Education Teaching as Yadnya in The Realization of Dharma Agama And Dharma Negara. Cakrawala Pendidikan, 34(2), 179. https://doi.org/https://doi.org/10.21831/cp.v2i2.4822

Komalasari, K., \& Saripudin, D. (2018). The Influence of Living Values Education-Based Civic Education Textbook on Student's Character Formation. International Journal of Instruction, 11(1), 395-410. https://doi.org/https://doi.org/10.12973/iji.2018.11127a

Lickona, T. (2013). Educating for Character. Batam Book. http://library.fip.uny.ac.id/opac/index.php?p=show_detail\&id=179

Megawangi, R. (2004). Pendidikan karakter: Solusi yang tepat untuk Membangun Bangsa. Star Energy. https://opac. perpusnas.go.id/DetailOpac. aspx?id=965627

Nurgiantoro, B. (2010). Sastra Anakk: Pengantar Pemahaman Dunia Anak. Gajah Mada University Press. 
Sanjaya, D. B., Suartama, I. K., Suastika, I. N., Sukadi, Dewantara, I. P. M. (2021). The implementation of balinese folflore-based civic education for strengthening character education. Cypriot Journal of Educational Science. 16(1), 303-316 https://doi.org/10.18844/cjes.v16i1.5529.

http://ugmpress.ugm.ac.id/id/product/budaya/sastra-anak-pengantar-pemahaman-dunia-anak

Parmini, N. P. (2015). Eksistensi Cerita Rakyat dalam Pendidikan Karakter Siswa di Sekolah Dasar Ubud. Jurnal Kajian Bali, 5(2). https://ojs.unud.ac.id/index.php/kajianbali/article/view/16784

Pramuki, E. B. (2011). Cerita Anak Sebagai Media Pembelajaran BI dalam Pembentukan Karakter Siswa SD. UNS.

Rachmah, H. (2013). Nilai-Nilai Dalam Pendidikan Karakter Bangsa Yang Berdasarkan Pancasila dan UUD 1945. EJurnal Widya Non-Eksakta, 1(1), 7-14. https://e-journal.jurwidyakop3.com/index.php/ejournalnoneksakta/article/view/134

Samsuri, \& Marzuki. (2016). Pembentukan Karakter Kewargaan Multikultural Dalam Program Kurikuler Di Madrasah Aliyah Se-Daerah Istimewa Yogyakarta. Cakrawala Pendidikan, 24(1). https://doi.org/https://doi.org/10.21831/cp.v1i1.8362

Sanjaya, D. B., \& Sukadi. (2018). Analisis Pembelajaran Karakter Sekolah Daasar di Kabupaten Buleleng. Laporan Penelitian. Undiksha: 2018.

Suarka, I. N. (2010). Kesusastraan Bali. Pelatihan Nyastra Tentang Pemantapan Pemahaman Pengajaran Bahasa.

Suartama, I. K., Setyosari, P., Sulthoni, Ulfa, S., Yunus, M., \& Sugiani, K. A. (2021). Ubiquitous Learning vs . Electronic Learning : A Comparative Study on Learning Activeness and Learning Achievement of Students with Different Self-Regulated Learning. International Journal of Emerging Technologies in Learning (IJET), 16(03), 36-56. https://doi.org/https://doi.org/10.3991/ijet.v16i03.14953 I

Suartama, I. K., Triwahyuni, E., Sukardi, A., \& Hastuti, W. D. (2020). Development of E-Learning Oriented Inquiry Learning Based on Character Education in Multimedia Course. European Journal of Educational Research, 9(4), 1591-1603. https://doi.org/10.12973/eu-jer.9.4.1591

Suryadi, A., \& Somantri. (2000). Pemikiran Ke Arah Rakayasa Kurikulum Pendidikan Kewarganegaraan. The Need for New Indonesian Civic Education.

Titib, M. (1995). Nilai-nilai Budaya Bali; Implementasinya dalam Tri Dharma Perguruan Tinggi. Universitas Udayana.

Ünal, F., \& Kaygın, H. (2019). Citizenship Education for Adults for Sustainable Democratic Societies. Sustainability, 12(56). https://doi.org/10.3390/su12010056

Winataputra. (2011). Civic Education (Konteks, Landasan, Bahan Ajar dan Kultur Kelas). Program Studi Pendidikan Kewarganegaraan Sekolah Pascasarjana UPI.

Winataputra, S. (2006). Civic Education (Konteks, Landasan, Bahan Ajar dan Kultur Kelas). PPs Universitas Pendidikan Indonesia.

Wuryandani, \& Wuri. (2014). Pendidikan Karakter Disiplin Di Sekolah Dasar. Cakrawala Pendidikan, 2(1), 286. https://doi.org/https://doi.org/10.21831/cp.v2i2.2168

Zuchdi, D. (2010). Pengembangan Model Pendidikan Karakter Terintegrasi Dalam Pembelajaran Bidang Studi Di Sekolah Dasar. Cakrawala Pendidikan, Spesial Is(Dies Natalis UNY). https://journal.uny.ac.id/index.php/cp/article/view/224 